\title{
Some Cytochemical and Cytophysiological Properties of the Cells from Tuberculoid and Lepromatous Lesions
}

\author{
W. A. HADLER \\ (Instituto de Morfologia, Universidade de Campinas; Campinas, Est. S. Paulo, Brasil)
}

The inoculation of $M$. leprae and $M$. lepraemurium into animals develops two types of lesion: (a) lepromatous lesion, that occurs in rats, mice and hamsters (Hadler, I 953; Hadler and Ziti, I 956); (b) Tuberculoid lesion, found in guinea pigs and rabbits (Hadler, I953). In a previous paper (Hadler, I 953) the histogenesis, the morphology and a few cytochemical properties of the inflammatory cells from these two types of lesions were studied. The results indicated that in the tuberculoid type of lesions the macrophages are able to lyse the phagocytised mycobacteria, becoming transformed, after the bacterial lysis is done, into epithelioid cells, free of bacilli and lipids. On the other hand, in the lepromatous type of lesions the macrophages were unable to lyse the phagocytized mycobacteria, transforming into lepra cells which contain numerous bacilli and lipid droplets within their cytoplasm.

In the present paper an attempt is made to study the cells from lesions induced by $M$. leprae and $M$. lepraemurium inoculated in guinea pigs, rabbits and rats, as far as some cytochemical and cytophysiological properties are concerned. In addition, human lesions of both tuberculoid and lepromatous type were also studied.

\section{MATERIAL AND METHODS}

Adult rats, guinea pigs and rabbits of both sex, weighing I 40-220g (rats), 310-365g (guinea pigs) and 2.000-2.500 (rabbits) were used.

Suspensions of $M$. leprae and $M$. lepraemurium, prepared by the usual methods and rendered free from tissue particles with the aid of the Hanks ( I 95I) technique slightly modified, were injected intracutaneously or intraperitoneally. The inoculated dose of bacilli was determined by weighing the already dried bacilli from a suspension sample. When the inoculation was performed by intracutaneous route the hair of a $5 \mathrm{~cm}$. skin area was previously shaved.

The animals were grouped according to the mycobacterial species inoculated, the route of inoculation with the additional injection of electro-negative colloidal particles (Table I). Two kinds of colloidal particles were employed: (a) I per cent Prussian blue water 'solution'; (b) I : 2 water diluted Indian ink. The Prussian blue was injected together with bacilli; the Indian Ink was injected either 24 or 48 hours before the animal was killed, except for the rabbits (see Table I).

\section{T A B LE I}

Throughout the experiment, the animals were killed by ether inhalation according to the following schedule: (a) groups I, 2 and 4: one or two animals daily until the 3 rd day and each three days until the 4oth day after inoculation; (b) groups 3, 5, 6 and 8: one animal at the 2nd, $5^{\text {th, }} 8$ th, I 2 th, I $5^{\text {th }}$ and 20 th day; of the remaining animals of the group, 8 were killed at the $25^{\text {th }}$, 3oth, $35^{\text {th }}$ and 4 oth day and those ones of group 3 at the 5oth, 6oth, 7oth and goth day.

Humans lesions from four lepromatous and four tuberculoid leprosy cases were also studied. In addition, the site of inoculation of the lepromin test performed in six positive and six negative contacts, taken up by biopsy, 20 days after the lepromin injection, were included in this study.

The histological study was performed in such a way that always one rat and one guinea pig subjected to the same experimental condition

\footnotetext{
*This study was supported by a research grant (E-376o) from the U.S. Department of Health, Education and Welfare, of the National Institute of Allergy and Infectious Disease.
} 
TABLE I

Experimental animals, dose of inoculum and route of inoculation

\begin{tabular}{|c|c|c|c|c|c|c|}
\hline \multirow[b]{2}{*}{ Group } & \multicolumn{3}{|c|}{ No. of Animals } & \multicolumn{2}{|l|}{ Inoculum } & \multirow{2}{*}{ Colloidal particles } \\
\hline & Rats & $\begin{array}{l}\text { Guinea } \\
\text { Pigs }\end{array}$ & $\begin{array}{l}\text { Mycobacterial } \\
\text { Species }\end{array}$ & $\begin{array}{l}\text { Dose in } \\
M g .\end{array}$ & $\begin{array}{l}\text { Route of } \\
\text { Inoculation }\end{array}$ & \\
\hline r & 25 & 25 & M. leprae & 0.5 & Intracut. & - \\
\hline 2 & 25 & 25 & M. lepraemurium & I.O & Intracut. & - \\
\hline 3 & Io & Io & M. leprae & 2.0 & Peritoneal & - \\
\hline 4 & 20 & 20 & M. lepraemurium & $4 \cdot 0$ & Peritoneal & - \\
\hline 5 & 6 & 6 & M. leprae & 0.5 & Intracut. & - \\
\hline 6 & 6 & 6 & M. lepraemurium & I.O & Intracut. & $\begin{array}{l}\text { Prussian blue o. I ml } \\
\text { Indian ink o. I } \mathrm{ml}\left(^{*}\right)\end{array}$ \\
\hline 7 & 6 & 6 & M. lepraemurium & $4 \cdot 0$ & Peritoneal & $\begin{array}{l}\text { Prussian blue o. I } \mathrm{ml} \\
\text { Indian ink } 1.0 \mathrm{ml}(* *)\end{array}$ \\
\hline 8 & Rabbits & & $\begin{array}{l}\text { M. lepraemurium } \\
\text { M. leprae }\end{array}$ & $\begin{array}{l}4.0 \\
0.5\end{array}$ & $\begin{array}{l}\text { Peritoneal } \\
\text { Intracut. }\end{array}$ & $\begin{array}{l}\text { Indian ink } 0.3 \mathrm{ml} \\
\text { injected together the } \\
\text { bacilli }\end{array}$ \\
\hline
\end{tabular}

(*) injected into the lesion, $24-48 \mathrm{~h}$ before the animal was killed.

could be compared; the rabbit and the human material were studied in parallel. Pieces of omentum, spleen, liver and lymph nodes, as well as the site of inoculation were taken up and treated as follows:

(I) General histological techniques: fixed in Bouin's fluid or in a solution containing 80 per cent ethanol $(85 \mathrm{ml})$, formalin (10 $\mathrm{ml}$ ) and acetic acid $(5 \mathrm{ml})$; embedded in paraffin and stained by HE, Masson's trichromic and orcein;

(2) Silver methods: (a) reticulum: fixed in a Io per cent formalin solution, embedded in paraffin and silver stained by Gomori's (I 937) technic; or frozen sections, silver stained by the Rio Hortega's (I 943) technique; (b) macrophages: fixed in a i 5 per cent formalin solution added, $3 \mathrm{~g}$ of calcium chloride to each $\mathrm{I}$ oo $\mathrm{ml}$ of solution; frozen sections, stained by a variant of the Rio Hortega (1927) method.

(3) Mycobacteria: Faraco's (1938) modification of Ziehl-Neelsen's stain technique;

(4) Athrocytic activity: fixed in Bouin, embedded

I 72 Leprosy Review
$(* *)$ injected by peritoneal route, $24-48 \mathrm{~h}$ before the animal was killed.

in paraffin and stained by $\mathrm{HE}$, or fixed in formalin-calcium solution, frozen sections and counterstained with carmine.

(5) Mitochondria: Fixed in Regaud's fluid for four days, postchromed for eight days and stained by Altman's fucsin-anilin.

(6) Histochemical techniques:

(a) Lipids: Two procedures were used: fixed in a formalin calcium solution, frozen sections stained by a 60 per cent ethanol saturated solution of Sudan black B; and fixed $24 \mathrm{~h}$ in a formalin calcium-cobalt solution, post-chromed for six days and stained by Sudan black B as for McMannus ( 1946) phosphatide technique.

(b) Alkaline phosphatase: Technique of Gomori ( $1946 \mathrm{a}$ ); sodium B glycerophosphate as substrate; incubation for $4 \mathrm{~h}$.

(c) Acid phosphatase: Technique of Gomori (r 950a) modified by Holt (r959); fixed in formalin calcium solution at $4{ }^{\circ} \mathrm{C}$; paraffin embedded in frozen section; substrate sodium $\mathrm{B}$ glycerophosphate; incubation for $2 \mathrm{~h}$. 
(d) Lipase: Technique of Gomori ( 1953 ): fixed in ethanol at $4{ }^{\circ} \mathrm{C}$ for $\mathrm{I} 2 \mathrm{~h}$ and embedded in paraffin; incubation $\mathrm{o} \mathrm{h}$ in between 40 , at $\mathrm{pH}$ 7.2 (0.05M veronal buffer).

(e) Basophil and metachromatic substances: Fixed in Bouin or ethanol-formalin-acetic acid solution, stained in a I per cent Toluidine blue solution, at $\mathrm{pH} 4 \cdot 5$. Ribonuclease test performed with a boiled acid extract of pancreas.

(f) Periodic acid Shiff reaction: Fixed in Bouin or ethanol formalin-acetin acid solution; McMannus (i 948) technique.

(g) Feulgen's reaction: Feulgen and Rossenbeck's ( I924) technique.

\section{RES ULTS}

The guinea pig and rabbit lesions are histologically similar and therefore they will be analysed together. There are no detectable histological and cytochemical differences concerning either the mycobacterial species or the inoculation route, when single animal species are considered.

The macrophage appears as a cell that plays a key role concerning the development and evolution of the leprosy lesions in all animal species studied, since this cell should be well identified. As an attempt to accomplish this purpose besides its morphology we have based its argentophil properties (Figs. I and 2), which seem to be very suitable in this connection.

The macrophage originates from a spindleshaped and slightly argentophil cell whose cytological and cytochemical properties are summarised in Table 2. Cytochemically this cell shows some quantative differences when guinea pig lesions are compared with rat lesions. Either the alkaline or the acid phosphatase activity, quantitatively estimated by the method of Cleland (1950), slightly modified, are higher in the guinea pig spindle-shaped cells rather than in the same cells from the rat lesions. It is known that such a method to estimate phosphatase activity is not suitable for quantitative purpose (Gomori, I950a, I 950b). However, in our material it proved to be useful since the results were uniform and permit a good comparison either among several cell types in a single animal species or between a same cell type in two animal species. Nevertheless, the results must be considered only as a semi-quantitative approach.
Table 2 shows the main morphological and cytochemical properties of the macrophage. Some quantitative differences could be seen concerning the guinea pig macrophages compared to the rat ones. These differences are cytochemical and cytophysiological in nature. The guinea pig and rabbit macrophages display a higher level of lipase, alkaline and acid phosphatase activity (Figs. 7, 9 and Io); they contain larger amounts of lipid droplets than do the rat macrophages. Although the macrophages in these three animal species are actively phagocytic, those of rat show larger amounts of bacilli inside the cytoplasm. The study of the lesions throughout its development show that the amount of mycobacteria progressively decreases within the guinea pig and rabbit macrophages; in the rat macrophages, on the other hand, the amount of bacilli increases progressively. As the amount of bacilli inside the cell depends upon the ratio between the uptake and the lysis of the phagocytised bacilli, this finding permits two hypotheses: (I) the rat macrophage display a higher degree of phagocytosis; (2) the guinea pig and rabbit macrophages are able to lyse the phagocytised bacilli.

The latter hypothesis is supported by following findings:

(a) The phagocytic activity seems to be similar in the rat and guinea pig macrophages, since both are able to take up Prussian blue and Indian ink particles at a same extent. It is known that athrocytic and phagocytic activity are parallel.

(b) In the rat macrophages the bacilli seldom lie within cytoplasmic vacuoli, and are morphologically normal and stain well; on the other hand in the guinea pig and rabbit macrophages the bacilli lie in cytoplasmic phagosomes, display marked and progressive morphological alterations, lose their alcohol-acid resistance and show some sudanophilia, in contrast with what happens with morphologically normal bacilli.

Furthermore, since the rat macrophages do not show any morphological sign of cell damage, the guinea pig and rabbit macrophages often present cytoplasm vacuolization, degenerative alterations of the nucleus (pyknosis, chromatolysis) and cell necrosis. These findings suggest a more striking integration of bacilli into host cells in these latter animal species. 


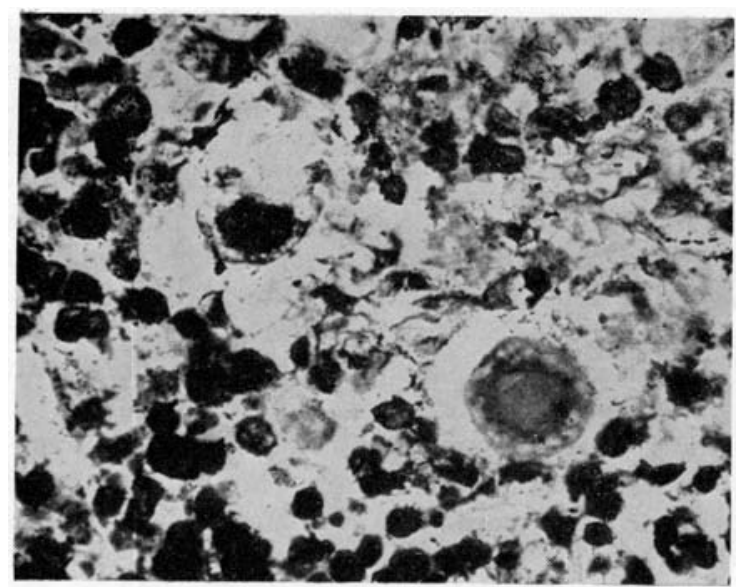

Silver satining method for argentophil cells; $320 \mathrm{X}$ FIG. I Rat intracutaneously inoculated with $M$. lepraemurium; skin lesion. The macrophages appear deep black; the lepra cells are slightly impregnated or unstained; the giant cell shows the central area moderately argentophil.

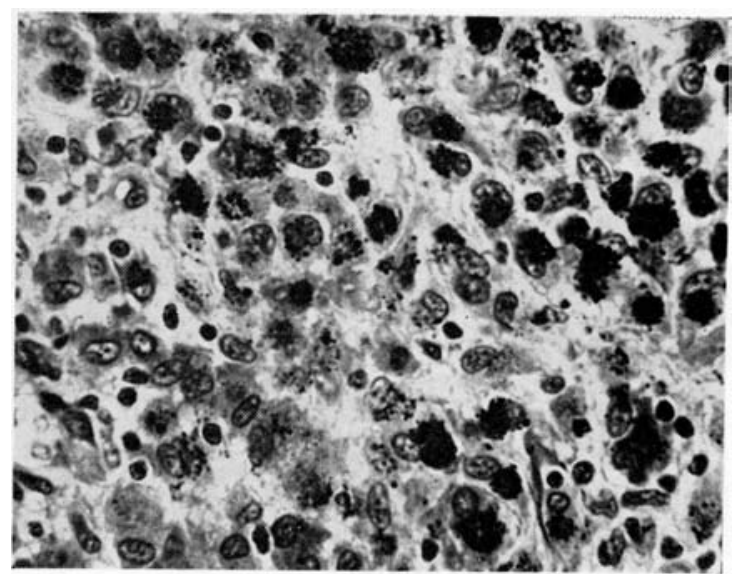

FIG. 3 Rabbit intracutaneously injected with $M$. leprae plus Indian ink; HE stain; 550X. The macrophages (top right) show a great amount of granules within their cytoplasm; the epithelioid cells (centre and left side) contain only a few granules arranged as a circle near the nucleus.

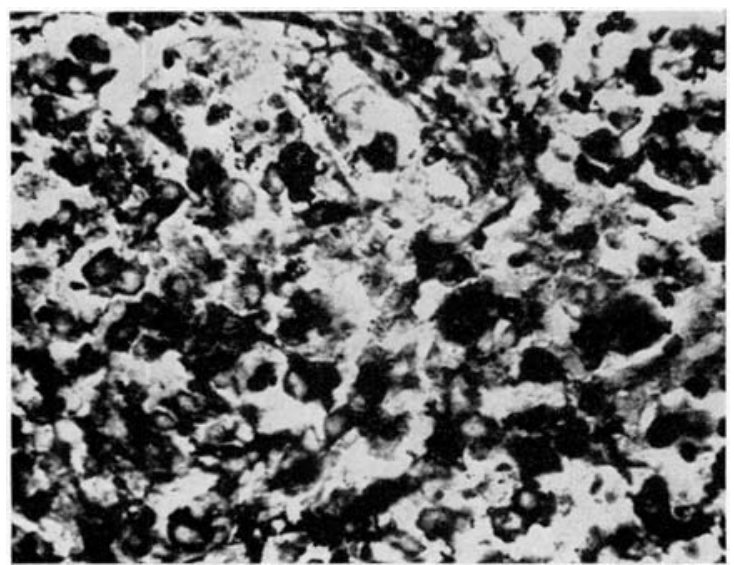

FIG. 2 Guinea pig intracutaneously inoculated with $M$. lepraemurium; skin lesion. The macrophages are strongly argentophil whereas the epithelioid cells are not stained.

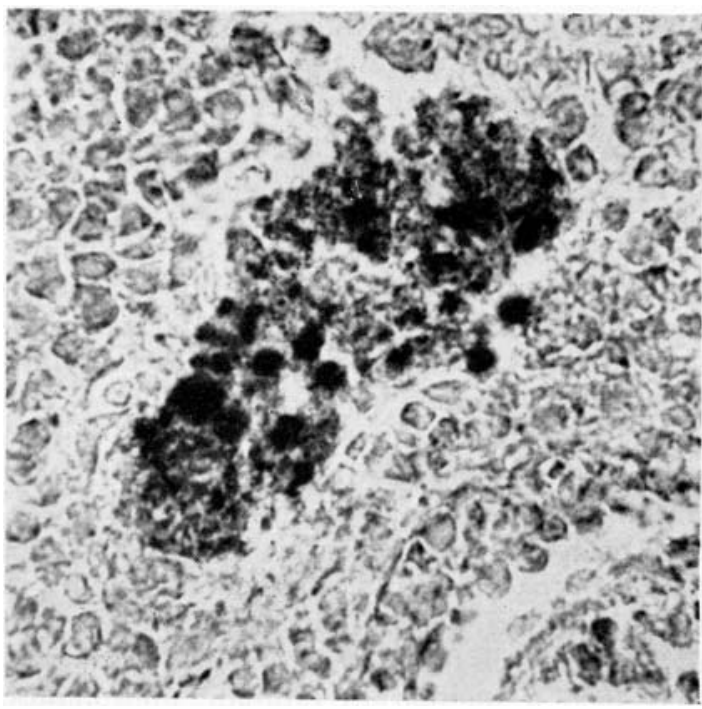

FIG. 4 Rat peritoneally injected with $M$. leprae; lymph node lesion; Sudan black B stained; 30oX. The lepra cells contain numerous sudanophil droplets within their cytoplasm. 
TABLE 2

\section{Cytological, cytochemical and physiological properties of the main cells found in lesions produced by mycobacteria inoculation into rat and guinea pig tissues}

\begin{tabular}{|c|c|c|c|c|c|c|}
\hline \multirow{2}{*}{ Properties } & \multicolumn{2}{|c|}{ Spindle-shaped Cell } & \multicolumn{2}{|l|}{ Macrophage } & \multirow{2}{*}{\multicolumn{2}{|c|}{$\begin{array}{ll}\text { Epithelioid } & \text { Lepra } \\
\text { Cell } & \text { Cell } \\
\text { (Guinea Pig) } & \text { (Rat) }\end{array}$}} \\
\hline & Guinea Pig & Rat & Guinea Pig & Rat & & \\
\hline Argentophilia & \pm & \pm & ++++ & ++++ & - & \pm \\
\hline Phagocytic activity $(*)$ & \pm & \pm & +++ & ++++ & - & ++++ \\
\hline Athrocytic activity $(* *)$ & \pm & \pm & ++++ & ++++ & - & +++ \\
\hline Mitochrondria & ++++ & +++ & ++++ & +++ & +++ & + \\
\hline Cell damage & - & $\longrightarrow$ & +++ & \pm & + & $\longrightarrow$ \\
\hline Sudanophil substances & + & + & +++ & + & + & +++ \\
\hline Phospholipids & - & 一 & +++ & \pm & + & - \\
\hline Basophil substances (RNA) & +++ & +++ & ++ & ++ & - & - \\
\hline Metachromatic substances & + & + & \pm & \pm & - & - \\
\hline PAS positive substances & - & $\longrightarrow$ & + & \pm & - & - \\
\hline Alkaline phosphatase & ++++ & +++ & +++ & ++ & ++ & \pm \\
\hline Acid phosphatase & ++ & + & +++ & \pm & +++ & - \\
\hline Lipase & +++ & ++ & +++ & \pm & ++ & - \\
\hline
\end{tabular}

(*) Phagocytic activity: estimated on the basis of the amount of bacilli within the cell cytoplasm.

The macrophages become transformed into epithelioid cells in guinea pig and rabbit lesions, and into lepra cells in the rat lesions.

The morphological and cytochemical properties of the epithelioid cells may be seen on Table 2. The morphological study supports the view that epithelioid cells are unable to phagocytise, since they do not contain within their cytoplasm bacilli nor other kind of alcohol-acid resistant substances nor Prussian blue and Indian ink granules. This finding suggests, furthermore, that all detectable substances liberated from the bacilli lysed by the macrophages are soon split off, as the macrophages develop into epithelioid cells.

The lesions from animals that have received bacilli plus Prussian blue or Indian Ink suspensions show much particulate matter within
(**) Athrocytic activity: estimated on the basis of the amount of colloidal granules within the cell cytoplasm.

the cytoplasm of the macrophages. As the macrophages transform themselves into epithelioid cells, the granules progressively decrease in size and reduce in number, and when the transformation is accomplished only a few granules lie on a very limited cytoplasmic area (Fig. 3).

There are strong morphological evidences suggesting that Prussian blue and Indian ink particles are slowly digested throughout the macrophage development. The rate of digestion of colloidal particles seems to be slower than the rate of bacillary lysis.

The results obtained by the injection of Indian ink into the lesions, performed $\mathrm{I}-2$ days before the animals were killed indicate that epithelioid cells do not show any evidence of athrocytic activity. 


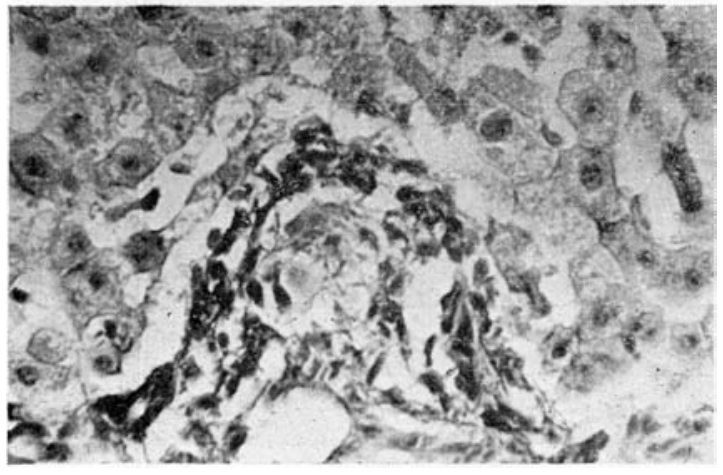

Alkaline phosphatase activity of the inflammatory cells. FIG.5 Rat peritoneally inoculated with $M$. lepraemurium; liver lesion; 300X. The lepra cells, which centre the lesion, are very slightly positive. The peripherally situated macrophages show a strongly positive reaction.

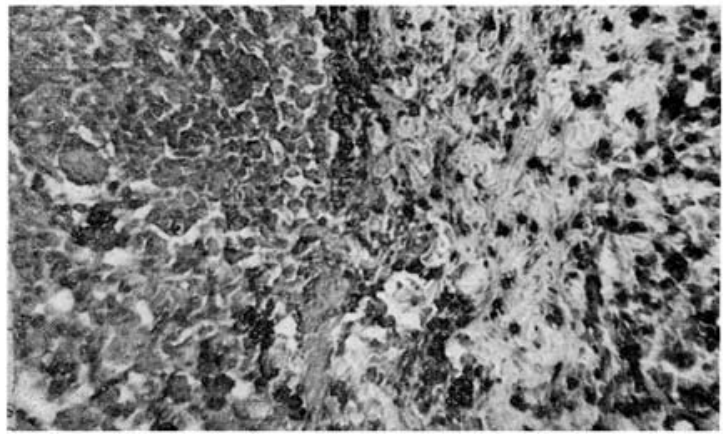

FIG7. Guinea pig peritoneally inoculated with $M$. leprae. Peritoneal lesion; IooX. The macrophages and the blood vessel endothelial cells (right side) are strongly positive. The epithelioid cells and the giant cell (left side) show a lesser degree of positivity.

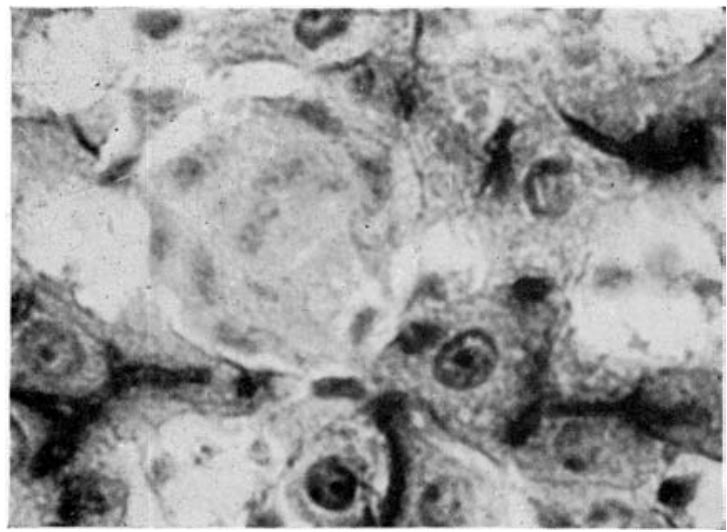

FIG.6 Rat peritoneally inoculated with $M$. leprae; liver lesion, 500X. The lepra cells that constitute the lesion are almost negative.

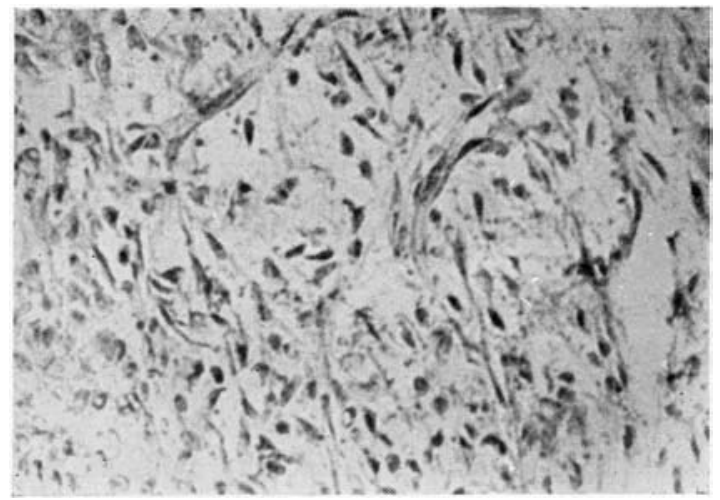

Acid phosphatase activity of the inflammatory cells.

FIG.8 Rat peritoneally inoculated with $M$. lepraemurium; peritoneal lesion; $300 \mathrm{X}$. The spindle shaped cells and the macrophages, show slightly positive reaction. The lepra cells that centre the lesion, are negative. 
The multinucleated giant cells, often found in guinea pig and rabbit lesions, are cytochemically and physiologically similar to epithelioid cells, except concerning its cytoplasmic central area. In this site, on the other hand, the described properties are closely alike to those of the macrophages.

In the rat lesions the macrophages transform themselves into lepra cells, which show many differences, mainly concerned with cytochemical and physiological properties, compared to the epithelioid cells (see Table 2 and Figs. 4, 5, 6 and 8).

The amount of bacilli within the cytoplasm of the lepra cells, although large, increases progressively throughout its development. As the bacilli injected were dead, this result supports the view that the lepra cells are able to phagocytise, in contrast to what happens with the epithelioid cells. The bacilli contained in the lepra cells often do not show morphological alterations at least before the second month of the evolution of the lesion. Only later some alcohol-acid resistant granules do appear. This finding indicates that lepra cells are unable to lyse the phagocytised bacilli, which remain stored within the cytoplasm for a long period. On the other side, the stored bacilli do not seem to produce any harmful effect upon the lepra cells.
When Prussian blue was injected together with bacilli, a large amount of dyed granules appeared scattered within the cytoplasm of the lepra cells, remaining there for a long time. There are no signs, in the most part of the lesions, that could be interpreted as an attempt of the lepra cells to digest the stored granules. Only in some limited sites of the lesions are there evidences of Prussian blue digestion, performed by the macrophages and by cells originated from them; these latter cells show physiological properties which differ from those presented by the true lepra cells (Hadler, I 959).

The lepra cells are able to take up Indian ink particles, injected I-2 days before the animals were killed. Nevertheless, the athrocytic activity of the lepra cells is at a lower degree compared to that of the macrophages. Only in the retrogressive phase of the leprosy lesions, which takes place two or more months after $M$. leprae inoculation, the lepra cells exhibit a higher degree of athrocytic activity, which becomes similar to that presented by the macrophages.

In the rat lesions some giant cells may be found. Although they are morphologically similar to those found in guinea pig lesions, physiologically and cytochemically they display the same properties as the lepra cells.

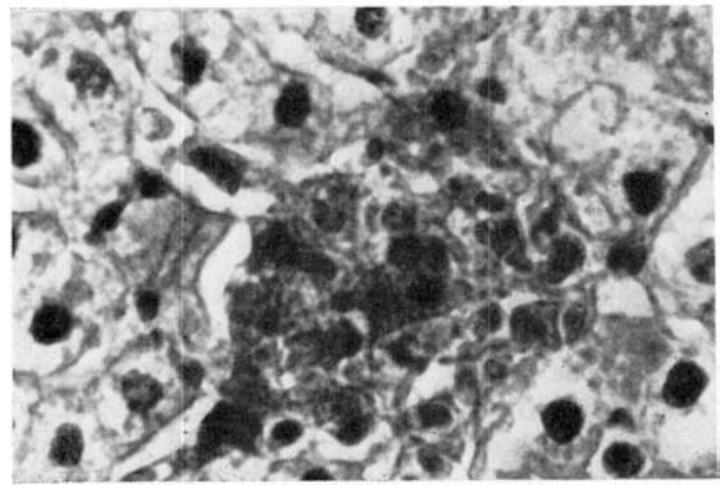

FIG.9 Guinea pig peritoneally inoculated with $M$. lepraemurium; liver lesion; $450 \mathrm{O}$. The epithelioid cells and the macrophages show strong positive reaction.

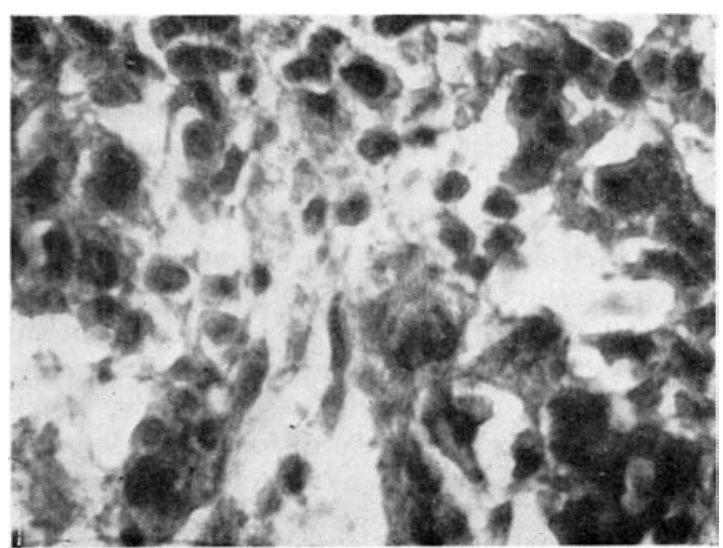

Fig. Io Guinea pig peritoneally inoculated with $M$. leprae; peritoneal lesion; 45oX. The macrophages show strong positive reaction; the larger epithelioid cells display a lesser degree of phosphatase activity. 
The results obtained with human material (leprosy lesions and the site of lepromin reaction) are very similar to those described above. The macrophage and the lepra cells of human lesions are almost identical to the homologous cells of the rat lesions, either cytochemically or physiologically. On the other hand, the macrophages and the epithelioid cells of human tuberculoid lesions are very similar to the homologous cells of the guinea pig and rabbit lesions.

\section{IS C USSION}

The stated results show that the rat lepra cells are very different cytochemically and physiologically from the guinea pig epitheloid cells. Some quantitative differences are also found when the macrophages of these two animal species are compared.

It appears that the macrophage is the most important cell as far as the histogenesis of lesions produced by mycobacteria is concerned. Therefore, a suitable staining method able to demonstrate this cell was considered as very desirable. Some silver staining techniques have been successfully used to impregnate the inflammation macrophage (Rio Hortega, I927, r 943; Rio Hortega and Asua, I92 I; Marshall, i 946, I953, I 958), since it is an argentophilic cell (Marshall, I953, I958).

The macrophage, therefore, well defined by silver impregnation, was taken as the central point of lesion development. On this basis, the cells that precede and succeed it could be well maintained and studied cytochemically and physiologically.

The lesions induced by $M$. tuberculosis inoculation into guinea pigs show that the macrophages are endowed with alkaline phosphatase activity, in contrast to what happens to the epithelioid cells which are inactive (Russel and col., I 944). Similar results have been obtained in tissue cultures (Weiss and Fawcet, I 953) and in human lesions of the tuberculoid form of leprosy (Klingmüller, r 953). Our results show, however, that either in animal or in human lesions, the epithelioid cells present alkaline phosphatase activity, although in a lesser degree compared to the macrophage. The alkaline phosphatase activity of epithelioid cells is larger than that presented by the lepra cells, which are almost inactive. In agreement with our findings, it has been pointed out that in the experimental rat tuberculosis the 'chronic inflammatory cells' do not show any alkaline phosphatase activity (Grogg and Pearse, I 952a), similar to that which occurs with the rat lepra cell (Klingmüller, I953).

On the other hand, our results do not agree with those concerned with the acid phosphatase activity of the inflammatory cells. It has been stated that both macrophages and epithelioid cells from tissue cultures (Weiss and Fawcet, I 953) and the 'phagocytes' from rat tuberculous lesions (Grogg and Pearse, I 952a) are provided with a high degree of acid phosphatase activity, in contrast with the guinea pig epithelioid cells which are inactive. Pepler and col. (1958) have found in human leprosy lesions more acid phosphatase activity in lepra cells than in epithelioid cells. It must be considered that it is very difficult to correlate cells defined by different criteria. Furthermore the semi-quantitative approach concerning the acid phosphatase activity performed by us, in a material where the macrophages were accurately recognised by its argentophilia, seems to be more suitable than other methods alrcady used to the same purpose.

Lipolytic enzymes such as stearases (Vogel, I 95 I) and lipase (Gomori, I946b; Wotton and col., I950) have been found in the guinea pig macrophages. On the other hand, the lepra cells do contain many lipid droplets within their cytoplasm (Rath de Souza and Alayon, I 942; Villela and Linhares, I 943; Linhares, I 944; Rath de Souza and Souza Lima, I950; Azulay and Andrade, r 952; Harada, I 955; Sugai, I 958) and show a feeble lipolytic activity (Emerson and col., I932), whereas the human epithelioid cells apparently do not contain lipids (Rath de Souza and Alayon, I942; Rath de Souza and Souza Lima, I950; Azulay and Andrade, I952). These results were confirmed by our findings.

Both the guinea pig and the rat macrophage show cytological similarities. Nevertheless, they display several physiological and cytochemical differences, which appear to be correlated with its ability to lyse the phagocytised bacilli Consistent evidences concerning the mycobacterial lyses within the guinea pig and rabbit macrophage are provided by the study of the lesions throughout their development and evolution. Electron microscopic studies performed on 
human tuberculoid leprosy lesions support this view (Nishimura, I960).

There should be some correlation between acid phosphatase activity, the functional role of the macrophage and its transformation into the epithelioid cell. This view is supported by the already admitted effectiveness of this enzyme in splitting off tuberculoid phosphatides (Grogg and Pearse, r952a; Gerstl and Tennant, I94I). As both alkaline and acid phosphatase as well as lipase appear at a higher level in the cells which are able to lyse the mycobacteria, it would be admitted that the enzymic production capacity by the cells has a great role concerning the bacterial lysis.

On the other hand, the biosyntheses or the activation of enzymes would depend upon the strength of cell stimulation. As the interaction of bacilli and host cells is closer in guinea pig lesions than in rat lesions, the different physiological behaviour of the inflammatory cells in these animal species would be a consequence of the effectiveness of the stimulus. Some experimental results support this hypothesis. Hadler ( I959) injecting electro-negative colloidal particles together, either the $M$. leprae or the $M$. lepraemurium in rats, found in limited areas of the lesions striking evidence of mycobacterial lyses performed within the macrophages. These cells further undergo transformation into epithelioidlike cells. This result was interpreted as a consequence of the enhanced stimulation effect of the rat macrophages accomplished by the interaction of the bacilli plus the colloidal particles. Hadler, Ferreira and Ziti (unpublished paper) inoculated guinea pig with $M$. leprae and $M$. lepraemurium and treated them with cortisone and an antihistaminic drug. Their findings show that the treated guinea pig macrophages become unable to lyse the phagocytised mycobacteria, and as a result lepra-like cells do appear in the lesions. In such instance, the treatment performed seems to inhibit the synthesis of the lytic enzymes by the macrophage, at the same time that the interaction of bacilli-host cells decreases. Therefore, by acting on the interaction of bacillihost cells the functional activity of the inflammatory cells may be experimentally changed.

The different behaviour of guinea pig and rat macrophages when $M$. leprae and $M$. lepraemurium are inoculated appears as a property of their own tissue cells, since it is independent of previous mycobacterial contacts (Hadler, I 953) and it is not modified by experimentally induced either specific or para-specific hypersensitivity (Hadler, I956; Hadler and Ziti, I 955).

\section{S U M M A R Y}

The lesions induced by $M$. leprae and $M$. lepraemurium inoculation in the guinea pig and rabbit display a tuberculoid structure, whereas in the rat they present a lepromatous structure. A cytochemical and cytophysiological study carried out on these two kind of lesion structures showed many differences concerning the biochemical and the functional activity of the macrophage, which seems to be responsible for the development of physiologically different cells: the epithelioid cell in the tuberculoid structure and the lepra cell in the lepromatous structure. The macrophage was considered as the most important cell concerning the lesion development and therefore was carefully identified, mainly by its argentophilia.

The guinea pig and rabbit macrophages, are able to lyse the phagocytised mycobacteria, and display a high degree of alkaline and acid phosphatase activity. They quickly split off lipids (phospholipids included) within its cytoplasm, since they present a high degree of lipase activity. They show numerous mitochondria and some ribonucleic basophilia in its cytoplasm. The macrophage transforms itself into the epithelioid cell, which is not argentophil, is free of bacilli and contains very few lipids within its cytoplasm. The epithelioid cell displays, furthermore, alkaline and acid phosphatase and lipase activity; it is a cell that does not display phagocytic and athrocytic activity, but it is able to split off the electro-negative colloidal granules already contained in its cytoplasm.

In the rat the argentophil macrophage is unable to lyse the phagocytised mycobacteria, shows a feeble alkaline and acid phosphase activity; splits off very slowly the lipids contained in its cytoplasm, which agrees with its very feeble lipase activity. In this animal species the macrophage transforms itself into the lepra cell, which is slightly argentophil, and contains a great amount of bacilli and of lipid droplets within its cytoplasm. This cell is void of lipase, alkaline and acid phosphatase activity and of ribonucleic basophilia. It is able to phagocytise and to athrocytise granular matter. 
The results obtained in human tuberculoid and lepromatous lesions were very similar to those stated before. In the tuberculoid lesions the macrophage and the epithelioid cell are similar to the homologous cells from guinea pig lesions. On the other hand, in the lepromatous lesions the macrophage and the lepra cell are similar to the cells found in the rat lesions.

The different behaviour of the inflammatory cells in these two types of lesions seems to depend upon the interaction of bacilli and host cells, which provides the stimulus concerning the biosynthesis of enzymes; some of them would be accounted for by the mycobacterial lysis. This hypothesis is supported by results concerning the experimental stimulation and inhibition of the inflammatory cells induced by the $M$. leprae and $M$. lepraermurium inoculation.

\section{RESUMO}

As lesões induzidas pela inoculação do $M$. leprae e do $M$. lepraemurium, em cobaios e coelhos, apresentam estrutura tuberculóide. No rato estas lesões possuem estrutura lepromatosa. $\mathrm{O}$ estudo citoquímico e citofisiológico, efetuado nesses dois tipos de lesões, mostrou diversas differenças concernentes à atividade bioquímica e funcional dos macrófagos, as quais parecem responsáveis pelo aparecimento de células fisiològicamente diferentes: a célula epitelióide na estrutura tuberculóide e a célula leprosa na estrutura lepromatosa. O macrófago foi considerado a célula mais importante no que concerne ao desenvolvimento das lesões e por isso, foi identificado cuidadosamente - principalmente através de sua argentofilia.

Os macrófagos do cobaio e do coelho são capazes de lisar as micobactérias fagocitadas e apresentam forte atividade phosphatásica, tanto alcalina quanto ácida. Eles metabolizam ràpidamente, lípides contidos em seu citoplasma e possuem forte atividade lipásica. Apresentam numerosas mitocôndrias e pequena basofilia ribonuclêica. $O$ macrófago transforma-se na célula epitelióide, que não é argentófila - não possui bacilos e contém poucos lípides no citoplasma; não exerce fagocitose nem atrocitose mas é capaz de metabolizar corantes eletronegativos contidos em seu citoplasma.

No rato, o macrófago argentófilo é incapaz de lisar as micobactérias fagocitadas; apresenta fraca atividade fosfatásica ácida e alcalina; metabolisa muito lentamente lípides contidos em seu citoplasma, o que concorda com sua fraca aftividade lipásica. Nesta espécie animal o macrófago transforma-se na célula leprosa, fracamente argentófila, muito rica em bacilos e em gotículas de lípides. Esta célula é isenta de lipase, de atividade fosfatásica ácida e alcalina e de basofilia ribonuclêica. A célula leprosa é capaz de fagocitar e atrocitar.

Os resultados obtidos em lesões de lepra humana confirmam os verificados em animais. Nas lesões tuberculóides o macrófago e a célula epitelióide são semelhantes às células homólogas presentes nas lesões do cobaio. Ao contrário, nas lesões lepromatosas o macrófago e a célula leprosa se assemelham às células emcontradas nas lesões do rato.

O comportamento diferente das células inflamatórias nesses dois tipos de lesões parecem depender da interação bacilos-células do hospedeiro, a qual produz estímulo responsável pela biosíntese de enzimas, algumas das quais produziriam a lise das micobactérias.

Esta hipótese é apoiada por resultados provenientes da estimulação e da inibição experimentais das células inflamatórias induzidas pela inoculação do M. leprae e do M. lepraemurium.

\section{B I B L I O G R A P H Y}

AZulay, R. D. and Andrade, L. M. C. The diagnostic value of lipoid in the various structural types of leprosy. Observation of ro53 cases. Internat. J. Leprosy, 20, 479-483, I 952. CLELAND, K. W. A study of the alkaline phosphatase reaction in tissue sections: I - The possibility of its quantitative use. Proc. Linnean Soc. New South Wales, 75, 35-53, I950. emerson, G. A., ANderson, H. H. and LeAke, C. D. Lipolytic activity of rat tissues in experimental leprosy. Proc. Soc. Exp. Biol. Med., 30, I 50-1 53, I $93^{2}$.

FARAco, J. Bacilos de Hansen e cortes de parafina: método complementar para pesquisa de bacilos de Hansen em cortes de material incluído em parafina. Rev. Brasil. Leprol. 6, I 77-186, 1938.

FEulgen, R. and Rossenbeck, H. Mikroskopisch - Chemischer Nachweiss einer Nucleinsaure von Typus der Thymonucleinsaure. Zeit. Phys. Chem., 135, 203-208, I924. GERSTL, B. and TENNANT, R. Enzymes as factors in resistance to tuberculosis. Am. Rev. Tuberc., 46, 600-6 I I, I 942.

GOMORI, G. Silver impregnation of reticulum in paraffin sections. Am. J. Path., 13, 993-1002, 1937.

GOMORI, G. New histochemical test for glycogen and mucin. Am. J. Clin. Path. 16, I 77-1 79, I 946.

Gomori, G. Study of enzymes in tissuesections. Am. J. Clin. Path. 16, 347-352, 1946.

GOMORI, G. Histochemical specificity of phosphatases. Proc. Soc. exp. Biol. and Med., 7o, 7-I I, I 949. 
GOMORI, G. Improved histochemical technic for acid phosphatase. Stain Tech., 25, 8I-85, i $950 a$.

GOMORI, G. Sources of error in enzymatic histochemistry. J. Lab. Clin. Med., 35, 8o2-8o9, i 95ob.

GOMORI, G. Chloroacylesters as histochemical substrates. J. Histochem. Cytochem., r, 469-470, I 953.

GROGG, E. and PEARSE, A. G. E. The enzymic and lipid histochemistry of experimental tuberculosis. Brit. J. Exp. Path., 33, 567-576, I 952.

HADleR, W. A. Comportamento do cobaio e rato normais injetados com 'lepromina' por via intradérmica. Rev. Basil. Leprol., 21, I 65-1 94, I 953.

HADLER, w. A. Influência da inoculaçao prévia de BCG sôbre os resultados da reaçao da lepromina, em cobaios. Bol. Serv. 15, 5-62, i 955 .

HADLER, w. A. The action of electronegative colloidal particles on the inflammatory reaction induced by Micobacterium le prae and $M$. lepraemurium in rats, guinea pigs and rabbits. Rev. Brasil. Leprol., 27, 9-1.5, I 959.

HADLER, W. A., FERreira, A. L. and ziti, L. M. An attempt to stimulate and depress the functional activity of the inflammatory cells from lesions experimentally induced by $M$. leprae and $M$. lepraermurium. To be published.

HADLER, W. A. and ZiTı, I. M. Estudo da reaçao da lepromina no rato prèviamente inoculado com $M$. lepraemurium $\mathrm{e}$ com $M$. tuberculosis (BCG). Rev. Brasil. Leprol., 23, 53-75, I 955 .

HADLER, W. A. and Ziti, L. M. Histological reactions produced by experimental inoculation of Micobacterium lepraemurium into the golden hamster (Cricetus auratus). Internat. J. Leprosy, 24, 397-306, I956.

hanks, J. H. Bacteriology of Leprosy. Ann. New York Acad. Sci., 54, I 2-I9, I95 I.

HARADA, K. Histochemical studies of Leprosy, especially the mode of formation of lepra cells. La lepro, 24, 277-282, I955.

HOLT, s. J. Factors governing the validity of staining methods for enzymes and their bearing upon the Gomori acid phosphatase technique. Exp. Cell. res. suppl., 7, I-27, I 959 .

KLINGmüller, G. On phosphatase in leprosy. Mem. VI Cong. Internat. Leprologia, Madrid, outubro 1953.

Linhares, H. Estudo sôbre a célula leprosa do rato. Mem. Inst. 'Oswaldo Cruz', 4o, I83-189, г 944.

mCmanus, J. F. A. Demonstration of certain fatty substances in paraffin sections. J. Path. Bact., 58, 93-95, 1946.

mamanus, J. F. A. Periodic acid routine applied to kidney. Am. J. Path., 24, 643-653, I 948.

MARShALl, A. H. E. Observations on the pulmonary macrophage system. J. Path. Bact. 58, 729-738, I 946.
MARShall, A. H. E. The reticular tissue and the 'reticuloendothelial' system. J. Path. and Bact., 65, 29-48, 1953.

MARShall, A. H. E. An outline of the cytology and pathology of the reticular tissue. Oliver and Boyd, London, 1956.

Nishimura, м. The electron microscopic basis of the pathology of leprosy. Internat. J. Leorosy, 28, 357-400, I 960 .

PAPLER, w. J., LOUBSER, E. and kOOIJ, R. A. A histochemical study of some of the hydrolytic enzymes in leprosy. Dermatologica (Basel), 117, 468-477, 1958.

RATH De Souza, P. and Alayon, F. L. Sôbre a presença de lipídeos nas lesoes cutâneas de lepra. Subsídio ao diagnóstico diferencial entre os diferentes tipos de lesao. Rev. Brasil. Leprol., ro, 37I-40 I, I 942.

RATH DE SOUZA, P. and souza lima, M. Sôbre o mecanismo da açao terapêutica dos derivados sulfônicos na lepra lepromatosa, r8, 59-68, i 95 o.

RIO HORTEGA, P. del. Innovaciones útiles en la técncica de coloración de la microglia y otros elemtos del sistema macrófógico. Bol. Real. Soc. espan. Hist. Nat., 27, I 99207, 1927.

RIO HORTEGA, P. del. El método del carbonato argentico. Revision general de sus técnicas y aplicaciones en la histologia normal e patológica. Arch. Histol. Normal y Pat., 2, 23 I-244, I 943.

RIO HORTEGA, P. del and ASUA, F. G. Naturaleza y caracteres de la trama reticular del bazo. Bol. Real. Soc. espan. Hist. Nat., 21, 37I-384, I $92 \mathrm{I}$.

Russel, W. O., READ, J. A. and Rouse, E. T. Morphologic and histochemical study of effect of scurvy on tuberculosis in guinea pigs and of origin, amount and distribution of alkaline phosphatase in foci of caseous necrosis. Arch. Path., 38, 31-39, I 944 .

SUGAY, K. Histopathological studies on human leprosy (IV). Histochemical analysis of abnormal fats in leprous lesions, especially on the fat deposition in lymph nodes. La Lepro, 27, 2 I 5-227, 1958.

Villela, G. G. and linhares, H. Lipídios na pele de ratos com lepra murina. Mem. Inst. 'Oswaldo Cruz', 38, 6I-64, I 943 .

VOGEL, F. S. A lipolytic enzyme in reactive histiocytes of guinea pigs with experimental encephalomyelitis. J. Exp. Med., 93, 305-313, i 95 I.

WEISS, L. P. and FAWCET, D. W. Cytochemical observations on chicken monocytes, macrophages and giant cells in tissue culture. J. Histoch. and Cytochem., r, 47-65, I 953. WOtTon, R. M., Ellinger, T. U. H. and BARTONE, J. C. Lipase reactions in phagocytes from peritoneum of rats toward previously stained fat. Anat. Rec., 107, 73-8 I, I 950 . 